Review

\title{
Tools for Small Hydropower Plant Resource Planning and Development: A Review of Technology and Applications
}

\author{
Petras Punys *, Antanas Dumbrauskas, Algis Kvaraciejus and Gitana Vyciene \\ Water and Land Management Faculty of the Lithuanian University of Agriculture, Kaunas, \\ Akademija, 10 Universiteto Str., LT-53361, Lithuania; E-Mails: antanas.dumbrauskas@1zuu.lt (A.D.) ; \\ algis.kvaraciejus@1zuu.lt (A.K.); gitana.vyciene@1zuu.lt (G.V.) \\ * Author to whom correspondence should be addressed; E-Mail: petras.punys@1zuu.lt or \\ punys@hidro.lzuu.lt; Tel.: +370-37-752-337; Fax:+370-37-752-392.
}

Received: 27 June 2011; in revised form: 22 August 2011 / Accepted: 22 August 2011 /

Published: 26 August 2011

\begin{abstract}
This paper reviews and compares software tools for the planning and design of small hydropower (SHP) plants. The main emphasis is on small scale hydropower resource assessment computer tools and methodologies for the development of SHP plants corresponding to a preliminary or prefeasibility study level. The paper presents a brief evaluation of the historic software tools and the current tools used in the small hydro industry. The reviewed tools vary from simple initial estimates to quite sophisticated software. The integration of assessment tools into Geographic Information System (GIS) environments has led to a leap forward in the strengthening of the evaluation of the power potential of water streams in the case of the spatial variability of different factors affecting stream power. A number of countries (e.g., Canada, Italy, Norway, Scotland and the US) have re-assessed their hydropower capacities based on spatial information of their water stream catchments, developing tools for automated hydro-site identification and deploying GIS-based tools, so-called Atlases, of small-scale hydropower resources on the Internet. However, a reliable assessment of real SHP site feasibility implies some "on the ground" surveying, but this traditional assessment can be greatly facilitated using GIS techniques that involve the spatial variability of catchment characteristics.
\end{abstract}

Keywords: small hydropower (SHP); GIS; software tools for SHP assessment 


\section{Introduction}

The assessment of SHP sites for development represents a relatively high proportion of overall project costs. A high level of experience and expertise is required to accurately conduct this assessment. Over the last several decades, a variety of computer-based assessment tools have been developed to address this problem and enable a prospective developer to make an initial assessment of the economic feasibility of a project before spending substantial sums of money. These tools range from simple first estimates to quite sophisticated programs. However, a reliable assessment of real economically feasible potential implies some "on the ground" surveying of possible sites and their electricity generation potential. Thus, the advent of Geographic Information System (GIS) software has been of enormous use as a way of capturing the range of information required, which is discussed further in this paper. These technologies can store spatial catchment information of a proposed SHP site in a GIS database and use it for decisions on whether to proceed with SHP plant development.

This paper reviews software tools and interactive maps/atlases that are deployed publicly on the Web and that indicate the locations of SHP sites and their main features. The main goal of these tools are the identification of potential SHP sites and the evaluation their energy output and environmental feasibility. Compatibility with environmental considerations is a crucial issue for the development of an SHP site before proceeding with a feasibility study.

This paper is based on the experience and expertise of the countries in which hydropower is highly developed, where specialised hydro software tools are extensively used for planning and designing SHP plants from a preliminary resource or site assessment up to a feasibility study. Only publicly available software assessment tools for SHP site development, which can be found in the available literature with clearly described computing algorithms, are presented. Obviously, for commercial software, the exact algorithms are mostly commercially sensitive, although, in some cases, their main features may be publicly available.

A comprehensive overview of the computer-based assessment tools used a decade ago for predicting the energy output of a particular small hydro scheme is given in [1]. The International Small Hydro Atlas also presents valuable information on SHP assessment tools and methodologies used all over the world [2].

The main aim of these software tools is to find a rapid and reasonably accurate means of predicting the energy output of a particular hydro scheme. These predictions involve establishing the "head" and the flow duration data that give the time variability of water discharge sufficiently accurately for capacity sizing of the plants. The first of these aims is a relatively simple matter of physical measurement, together with some hydraulic loss calculations concerning pipe materials, water velocities, and other variables. The second is much more difficult for SHP site investigation, and this part of the problem is the most intractable. There is no problem in assessing natural stream water energy from long time river flow records, which is not true for short period flow records and which is even more complicated for ungauged sites. Needless to say, the accuracy of hydrological analysis is crucial for the cost effectiveness of a hydro scheme [3].

In the US, the first GIS layers of SHP potential $(<1 \mathrm{MW})$ available openly to the public were produced in 2004 [4]. The suitability of individual hydropower sites was evaluated using GIS 
proximity analysis. Based on these datasets, an interactive hydropower atlas was developed, which is now available for public display on the Web [5].

To better understand the hydro resources available at the regional and local scales, a GIS study to determine the quantity and size of potential micro-hydro projects within a sample county in the US was performed [6]. A GIS-based map of the county was constructed with layers for property ownership and boundaries, elevation, stream locations and federal and state protected areas. Using a basin-specific GIS application, StreamStats [7], capable of computing estimates of streamflow at ungauged sites and estimated elevation change, the stream power was calculated using a conventional formula.

For a preliminary hydropower site assessment in a Brazilian river catchment, a software coupled with GIS and remote sensing data (satellite images) was used and generated a digital elevation model (DEM) and incorporated river flow data of the catchment [8].

GIS techniques were used to identify suitable SHP sites in Tanzania [9], and the outcome was a map with an index that aggregated hydrologic, demographic, economic and other attributes. Later, in South Africa, a preliminary assessment of micro- and macro-hydro power potential was undertaken by estimating the actual energy calculated from digital maps of river basins and runoff [10].

In India, a hilly stream catchment was considered for the assessment of hydropower potential using spatial tool GIS and a hydrological model [11]. In this country, prospective sites for SHP development were determined using remote sensing data (satellite images) [12]. The application of GIS to the site selection of a small run-of-river hydropower project by considering engineering, economic and environmental criteria and the social impact was also employed [13].

In Sri Lanka, a user friendly GIS was developed and applied to effectively create, store, manipulate, analyse and present the information relevant for the identification, investigation, design, monitoring and control of the operations of proposed and existing mini-hydropower plants [14]. In South Korea, a GIS-based methodology to identify suitable SHP sites by geospatial criteria was proposed [15].

In Europe, one of the first attempts to include spatial catchment attributes to estimate small-scale hydropower potential at any location was made by [16].

In Switzerland, using the ArcGIS 9.2 Spatial Analyst extension, a DEM for a small catchment area $\left(2800 \mathrm{~km}^{2}\right)$, and numerical flow data, suitable SHP locations were identified, and their characteristics were compared with those of plants already in operation [17]. A project called SMART that considers numerical methods, GIS databases and public cadastre for SHP development presents an interactive GIS- and Web-based SHP atlas [18,19]. This atlas (SMART Web-GIS) displays possible SHP sites by taking into account various limiting environmental factors and provides SHP plant power characteristics.

On the agenda of recent SHP conferences organised in Lausanne (Switzerland) and Vancouver (Canada), one of many items discussed was the new computer tools for SHP site assessment using GIS technologies [20-23].

The main aim of this study was to review publicly available software tools and interactive Web-based maps designated for SHP site identification, with the assessment corresponding to levels from reconnaissance up to pre-feasibility studies. 
The overall objectives of the study were to:

- Review computer programs and interactive maps on the Internet that are publicly available and designated for hydropower resource evaluation for SHP planning and designing purposes;

- Determine the possibilities for their practical application, stressing their main features;

- Reveal the possibilities of current applications of GIS technologies for conducting hydropower studies;

- Summarise good practices of these technologies for hydropower resource assessment and real site location by means of automated GIS procedures.

\section{Methodology}

The study object is small-scale hydropower resources or potential that are needed for planning and designing SHP plants. Computer programs intended for modelling hydromechanical equipment (for instance, turbines), such as Computational Fluid Dynamics (CFD); civil, geotechnical and other relevant hydropower engineering; and project cost issues including detailed design studies, are considered beyond the scope of this paper and are not discussed.

Neither SHP resources nor SHP plants have been distinguished according to any component. In common practice, a virtual size limit is fixed for small hydropower plants. Their size, usually determined by installed capacity, varies greatly from a few kilowatts to $50 \mathrm{MW}$ [24].

According to their purpose, software tools and interactive maps (atlases) deployed on the Web and designated for hydropower resource development can be distinguished between resources planning and designing studies (Figure 1).

Figure 1. Software tools used for hydropower assessment.

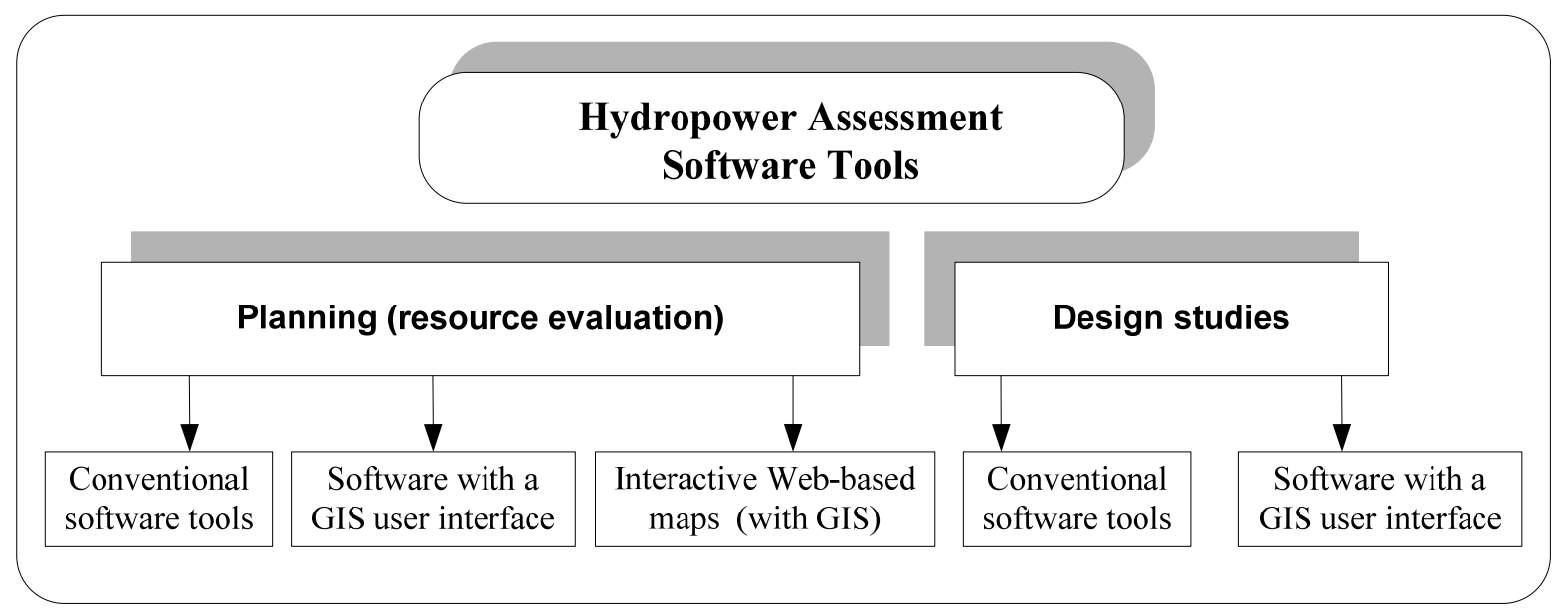

Reconnaissance resource studies or the first SHP planning level are conducted to find potential energy sources and to estimate the energy available in streams and may not be too site specific. In the past, to conduct this initial hydropower assessment, contour maps were typically used, assisted by standard computer programs. Based on the available head and mean annual flow or flow duration curve (FDC) in the stream, the capacity and energy output were determined. These hydrologic characteristics were determined using common methods. This classical methodology, which became more accurate, convenient and rapid, is aided by GIS based tools and other GIS integrated solutions. 
Design software is used for performing real hydropower projects, falling under prefeasibility or even feasibility studies, after which a final design is made or construction is initiated. Hydrologic data analysis assisted by specialised hydrologic software estimates the flow available for energy development and is a first crucial component of a hydropower project, clearly determining its feasibility. A variety of information resulting from a range of publications in open sources, conference proceedings and internet resources on the application of computer programs and integrated GIS for the planning and design of small hydropower plants was collected and analysed.

\section{Results and Discussion}

\subsection{Conventional Software Tools for SHP Assessment}

Computer software designated for SHP assessment can be integrated or not into GIS (i.e., using the spatial data of a catchment). Only the latest computer-based packages have integrated GIS tools or vice versa-some of them are a part of GIS (Figure 1). To assess river flow, there are two main approaches: the flow duration curve (FDC) and the simulated streamflow (model) methods. A less accurate intermediate approach is based on the mean annual flow (MAF), which can also be used in some programs. Table 1 summarises the software packages applied for hydropower studies.

Most of these software tools were developed nearly two decades ago, and some of them (for instance, RETScreen ${ }^{\circledR}$ ) have been constantly improved. At that time, some programs were regarded as promising, but ultimately they did not find a practical application. For instance, HydrA (European Atlas of Small scale hydropower resources), a PC-based software package, which was first developed in the UK and later in Spain, was designed for rapidly estimating small-scale hydropower potential at any location, at gauged or ungauged sites, to identify suitable turbine types [16]. The same fate occurred with the Lithuanian SHP atlas [25] because a relatively narrow hydropower market could not support its practical application.

The integrated method for power analysis (IMP) is a convenient tool for evaluating small-scale hydroelectric power sites [26,27]. By utilising IMP (combined with the relevant meteorological and topographical data), in approximately one day of in-house study, an experienced user can evaluate all aspects of an ungauged hydro site, which includes a power study, the development of a flood frequency curve and a fish habitat analysis.

RETScreen $^{\circledR}$, a very easy to use Microsoft Excel-based software, was developed by Natural Resources Canada and is available free from their website [28,29]. It enables the user to facilitate project development in various renewable energy and energy efficiency projects, which includes assessment of the potential for hydro based on the FDC or MAF of the site. It also determines the main financial information for the project, including initial capital cost and payback, and calculates avoided $\mathrm{CO}_{2}$ emissions.

PEACH software is dedicated to preliminary studies of hydropower sites [30,31]. It considers all technical engineering methods, usually used at these preliminary stages, and also deals with economic and financial analysis of hydropower schemes. 
Table 1. Overview of conventional software tools for SHP assessment.

\begin{tabular}{|c|c|c|c|c|c|c|c|}
\hline \multicolumn{3}{|c|}{ Software Tools } & \multicolumn{5}{|c|}{ Features } \\
\hline Name & Developer & $\begin{array}{l}\text { Applicable } \\
\text { countries }\end{array}$ & Hydrology & $\begin{array}{l}\text { Power } \\
\text { and } \\
\text { energy }\end{array}$ & Coasting & $\begin{array}{l}\text { Economic } \\
\text { evaluation }\end{array}$ & $\begin{array}{l}\text { Preliminary } \\
\text { design }\end{array}$ \\
\hline $\begin{array}{l}\text { Integrated method for power } \\
\text { analysis (IMP) [27] }\end{array}$ & $\begin{array}{l}\text { Natural Resources } \\
\text { Canada and POWEL }\end{array}$ & International & Model & + & - & - & - \\
\hline RETScreen $^{\circledR}[29]$ & $\begin{array}{l}\text { Natural Resources } \\
\text { Canada }\end{array}$ & International & FDC & + & + & + & - \\
\hline PEACH [31] & $\begin{array}{l}\text { ISL Bureau } \\
\text { d'Ingénieurs Conseils, } \\
\text { France }\end{array}$ & International & FDC & + & + & + & + \\
\hline $\begin{array}{l}\text { Hydropower Evaluation } \\
\text { Software } \\
\text { (HES) [33] }\end{array}$ & $\begin{array}{l}\text { Department of Energy, } \\
\text { Idaho Engineering and } \\
\text { Environmental } \\
\text { Laboratory, USA }\end{array}$ & USA & MAF & - & - & - & - \\
\hline SMART Mini Idro [18] & ERSE SpA, Italy & Italy & FDC & + & + & + & - \\
\hline Hydrohelp [34] & $\begin{array}{l}\text { Gordon J.L and OEL- } \\
\text { HydroSys, Canada }\end{array}$ & International & FDC & + & + & + & - \\
\hline
\end{tabular}

Modified and updated from the International Small Hydro Atlas [2]. 
The Hydropower Evaluation Software (HES) enables the user to account for environmental, legal and institutional constraints in the US [32,33]. It uses environmental attributes and federal land code data to generate a project environmental suitability factor.

Software SMART MINI IDRO based on the Excel platform is intended for preliminary SHP studies [18]. Power and energy are calculated using FDC and the type of turbine. Preliminary economic and financial estimates are also available.

HydroHelp includes a series of programs that enables hydro engineers to develop detailed preliminary cost estimates for power plant sites by providing expert advice throughout the design-cost process [34]. It offers a six-turbine selection feature to help promoters and designers choose the most appropriate turbine for a given site and market conditions.

\subsection{GIS Applications for Evaluating Hydropower Potential}

A variety of geographic information system (GIS) definitions are in use. For the purposes of this paper, they can be simply described as a system integrating hardware, software, and data for capturing, managing, analysing, and displaying all forms of geographically referenced information [35]. GIS enables one to view, understand, interpret, and visualise data in many ways that reveal relationships, patterns, and trends in the form of maps, globes, reports, and charts. A GIS also can be outlined as a suite of computer-based decision support tools for the integration of spatial data from different sources and for the analysis, manipulation and display of these data. It is, therefore, a powerful tool for the management of water bodies, such as river basins, with large amounts of spatially distributed data with all the advantages of a computer capability.

Land and forest surveys were the first applications of real GIS. Later, GIS technology was successfully applied to visualise water resources and river networks. Very rapid accumulation of GIS-based data encouraged the development of GIS analysis tools. GIS users from different fields could easily share information and compare spatially referenced data, overlay different GIS layers and obtain new information.

The first steps of GIS applications for the estimation of hydropower resource in river basins were made in the UK [16]. In many countries, spatial data are provided for free, which makes many tasks of specific fields easily resolvable.

An especially important step in GIS history was the development of DEM (Digital Elevation Model). They enable the study of land forms and, in a very short time, can access many hydrological and morphometric characteristics of a river basin. The input data for DEM generation comes from different sources, e.g., raw LIDAR (Light Detection and Ranging) data, old topographical maps, satellite images or aerial photography. Each source requires different technologies for data processing and gives a different result considering DEM accuracy and costs of data processing. Analysing DEM together with other data layers (e.g., soil data, land use, and protected areas) more based and accurate estimations of hydropower planning are obtained that take the already existing network of hydropower into consideration. A general GIS application flowchart for estimating hydropower resources is presented in Figure 2.

Using LIDAR technology only for SHP projects is currently too expensive and cannot compete with the common practice of DEM generation $[23,36]$. However, this situation is rapidly changing 
because this technology is used in very different practical fields (such as geodetic works, flood mapping, forests, and road development). By overlaying a segmented river network over the DEM, the elevation drop for each river reach can be obtained easily. By integrating runoff time series, flow duration curves, and annual flow data in GIS based models, power and energy maps can be produced. More detailed steps are described in Figure 3.

Figure 2. GIS hydropower assessment tool. General model process flowchart.

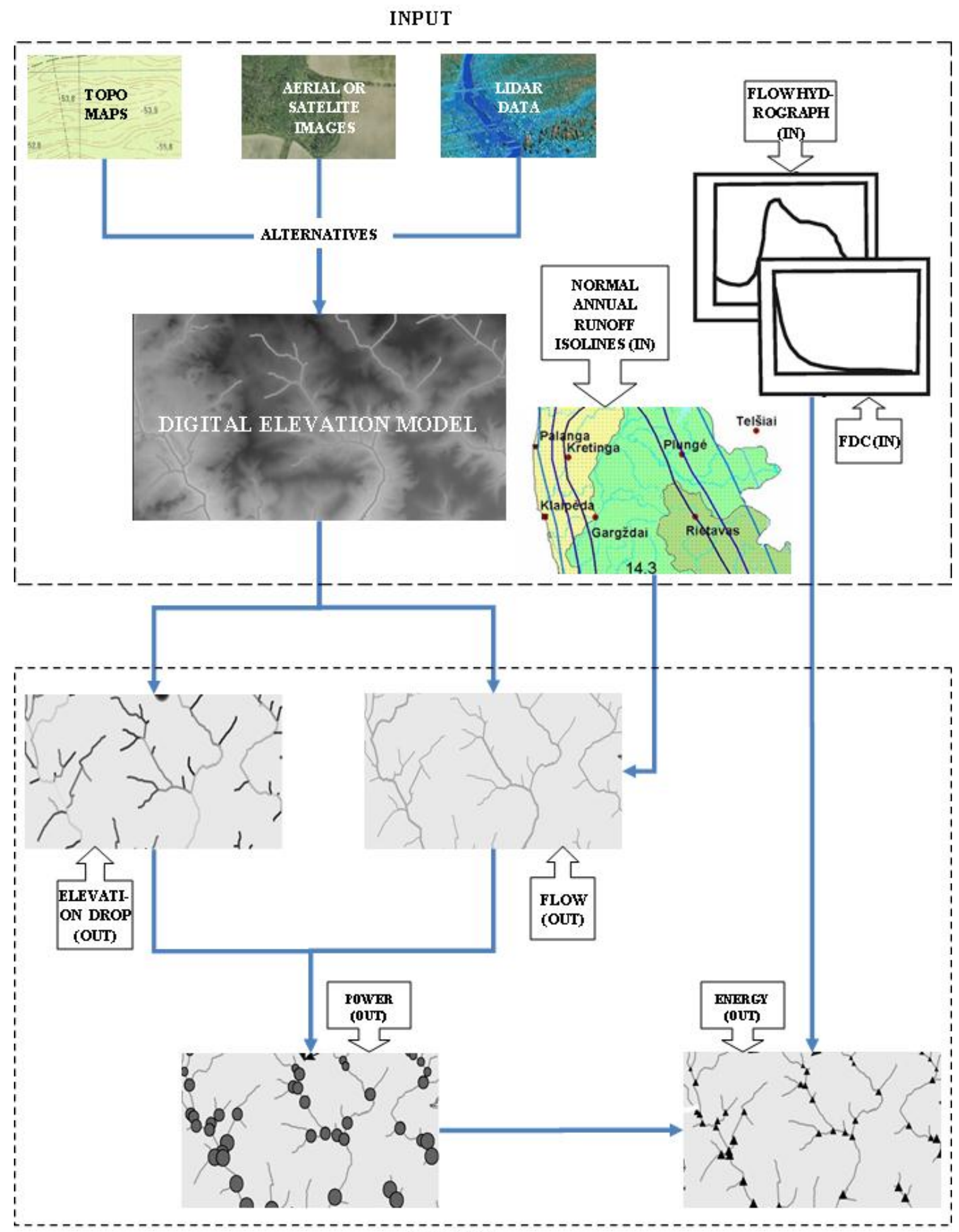


Figure 3. Detailed scheme of GIS application for hydropower estimation in the river basin: (a) The river basin foreseen for hydropower development. A-catchment area, H-elevation drop, Q- stream flow, P-stream power; (b) The river split into equal reaches $\left(h_{5}, h_{6}, h_{7}\right.$-elevation of water level at the end of river reach). The input data: hydrographic network and DEM of river basin; (c) Estimation of stream segment catchment area. The input data: hydrographic network and river catchment area with DEM; (d) Calculation of monthly river flow for every segment to obtain the input data from GIS layers; (e) Calculation of hydropower potential; (f) Evaluation of limiting factors for every reach (such as protected areas, agriculture, and forests).

(a)

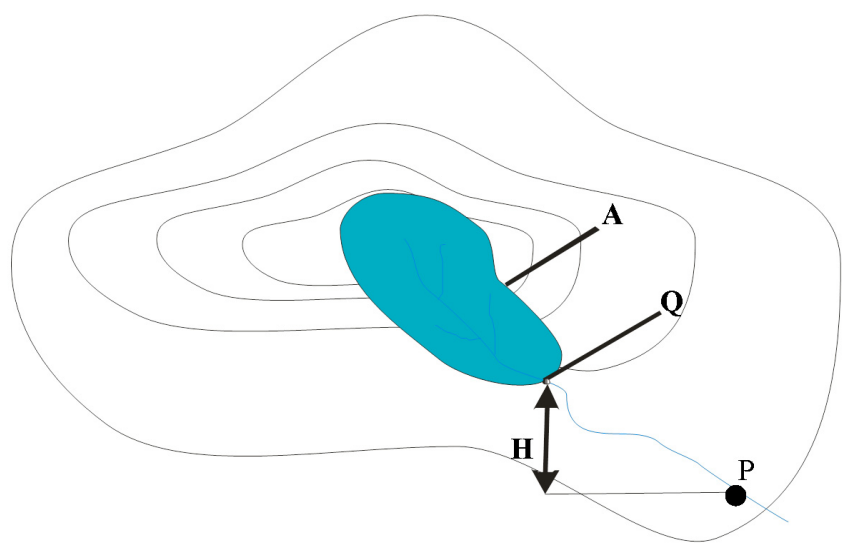

(c)

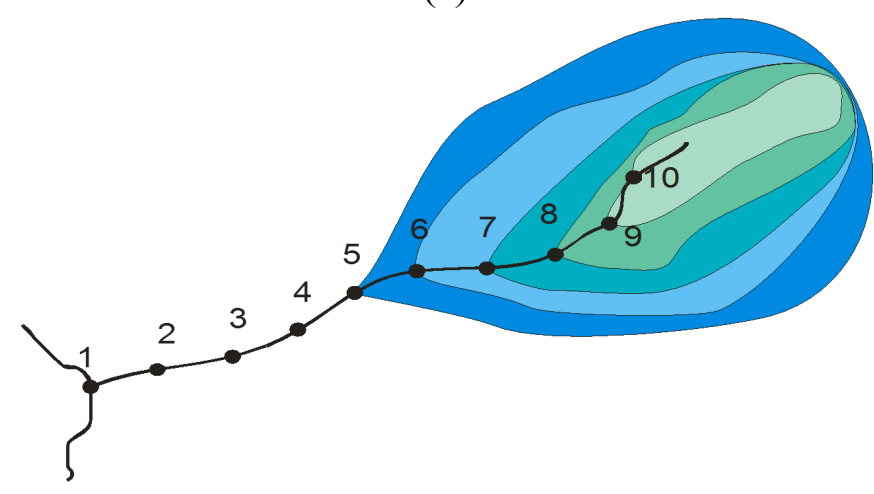

(e)

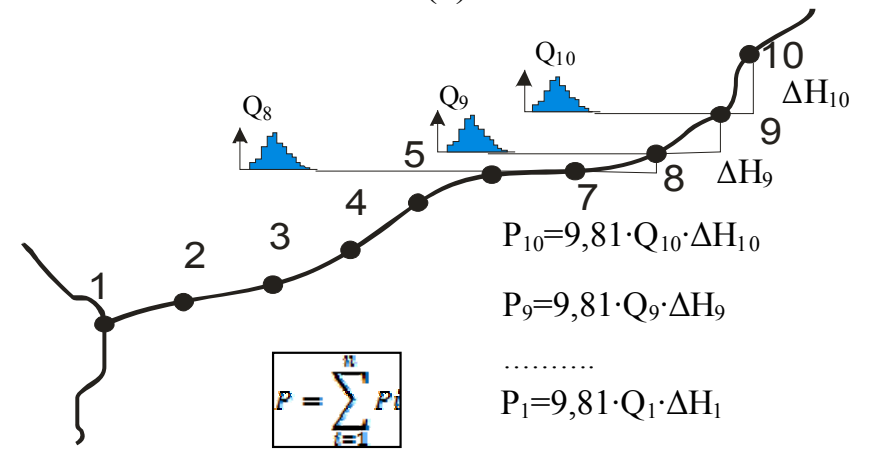

(b)

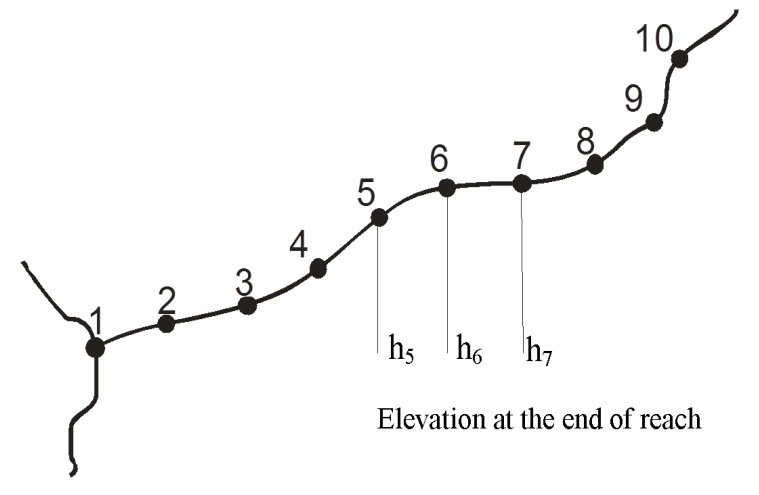

(d)

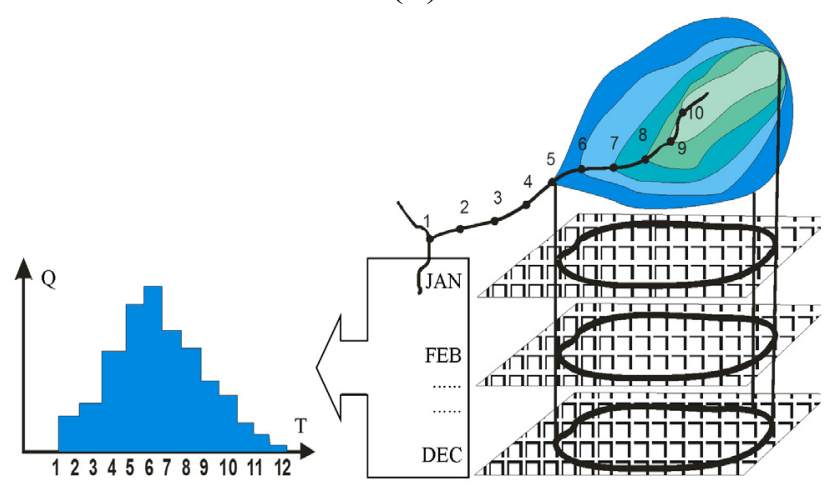

(f)

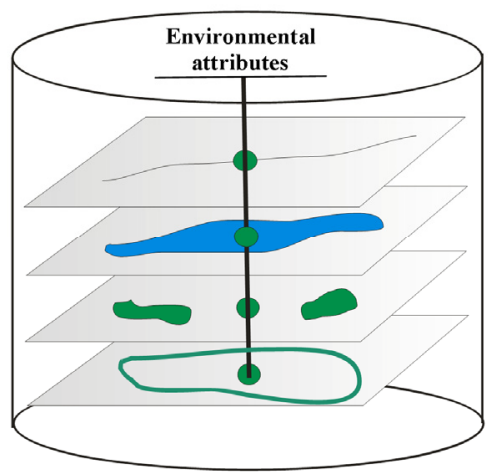


The input data are the hydrographic network layer and the digital elevation model. First, the river course is automatically divided into equal segments using the usual tools of GIS (Figure 3b). Second, at each division point going down from the upstream and using a specially developed GIS tool and the DEM, the basin area up to the determined section is calculated (Figure 3c). With the catchment area and applying the usual methods of hydrological calculations, the monthly basin runoff is computed (Figure 3d). With the elevation drop and runoff for each section, the stream power can be easily calculated (Figure 3e). This procedure is performed for each river segment from the upper to the lower reaches of the river and estimates all of the potential. It is absolutely clear that multiple environmental considerations reduce the likelihood that a site may be developed to its physical potential. Therefore, screening out sites within parks and other environmentally sensitive or excluded areas will result in the actual hydropower potential (Figure 3f).

Analysing the application of GIS software for potential assessments, the common ArcGIS tools developed by ESRI (Environmental Systems Research Institute) are generally used. Especially suitable tools are ArcGIS Spatial Analyst and the recently developed ArcGIS extension, ArcHydro [37], which allows the user to set a number of hydrological parameters used by hydrologic models as input data. Many hydrological models as they are today, without the use of GIS for the preparation of input data, cannot be used. Each hydrological model requires much of the input data prepared by other means, and the use of GIS would be either impossible or uneconomic. Using the DEM of the river basin, soils and land cover thematic layers and the river network, the number of required input data for the hydrological model, a sub-basin separation procedure and similar can be quickly and efficiently calculated.

The same can be said of 1D or 2D hydraulic models. Only with the proper tools of GIS can a detailed digital model of the surface be developed for the river bed and its valley, including the erected dams as well as the surface roughness distribution along the river bed [38].

A separate case of GIS application is the development of the map with a spatial distribution of FDC parameters. The parameters of the FDC obtained at the point of gauging stations are transferred to the attribute table of the new GIS layer and are later used for spatial analysis. By applying appropriate methods for the spatial interpolation of these parameters, their values can be determined for the ungauged river basins.

\subsection{Review of Case Studies for SHP Assessment Based on GIS Tools}

An analysis of the advanced experience in a number of countries using GIS technology for the assessment of hydropower resources and potential construction sites is analysed. Some countries have developed interactive maps of these resources, which are available on websites indicating site locations and the main technical and economical parameters, enabling users freely obtain the necessary information, while others do not display the data on the Internet or provide it to a limited extent.

\subsubsection{Canada}

In 2007, the Rapid Hydropower Assessment Model (RHAM) developed by KWL [39] was used to assess the run-of-river hydroelectric potential for the Province of British Columbia (BC), Canada, for an area of approximately 950 thousand square kilometres [20]. Over 8000 potential hydroelectric opportunities were identified. A powerful geographic information systems-based computer model 
enabled the assessment to be completed in four months. RHAM was developed using an ArcGIS 9.2 platform with the Spatial Analyst extension from ESRI Canada. GIS data sources incorporated into the model included DEM data from Natural Resources Canada and hydrology data from the B. C. Ministry of Environment (Table 2). RHAM was run for the entire province.

Table 2. Data sources for hydropower assessment [39].

\begin{tabular}{|l|l|l|l|}
\hline Dataset Data Type & Accuracy & Source & Description \\
\hline $\begin{array}{l}\text { Canadian Digital } \\
\text { Elevation Data }\end{array}$ & $\begin{array}{l}\text { DEM/1:250K } \\
\text { resolution }\end{array}$ & Geobase & Continuous representation of surface relief \\
\hline $\begin{array}{l}\text { Normal Annual } \\
\text { Runoff Isolines }\end{array}$ & $\begin{array}{l}\text { Vector/500 mm } \\
\text { contour interval }\end{array}$ & LRDW & Normal annual depth of runoff \\
\hline BC Watershed Atlas & $\begin{array}{l}\text { Vector/based on } \\
1: 20 \mathrm{~K} \text { mapping }\end{array}$ & $\begin{array}{l}\text { LRDW/Water } \\
\text { Management } \\
\text { Branch }\end{array}$ & $\begin{array}{l}\text { Topographic reference for mapped } \\
\text { hydrologic features }\end{array}$ \\
\hline HYDAT Data 2005 & Tabular & $\begin{array}{l}\text { Water Survey } \\
\text { Canada (WSC) }\end{array}$ & $\begin{array}{l}\text { Daily flow data recorded and archived by } \\
\text { WSC for all of Canada. }\end{array}$ \\
\hline Hydrologic Zones & Vector/1:2M & LRDW & $\begin{array}{l}\text { 29 regions of hydrologically similar areas } \\
\text { in BC }\end{array}$ \\
\hline
\end{tabular}

Using DEM and mean annual run-off information, the unique algorithm of RHAM can identify every significant stream and river within a given area, their respective flow rates throughout the year, and the maximum elevation drops along each reach within a given distance. The model does this by running both a topographical and a hydrological analysis simultaneously. RHAM calculates the amount of hydroelectric power available on all streams in a study area, screening out sites within parks and environmentally sensitive areas, and estimates project costs.

Although the model performed well from the beginning, KWL made adjustments to ensure that it provided accurate results. For example, in some flat areas, the engineers corrected the DEM data to ensure that streams flowed in the correct direction.

RHAM can also assess the suitability of hydroelectric development in a given area, taking into account economic, environmental and social factors, and can assess storage hydro and clustered developments. For British Columbia, this software tool is available on the Internet [40]. RHAM is being applied in other parts of the world to unlock hydroelectric potential.

\subsubsection{France}

For the evaluation of hydro potential at a regional scale in France, an innovative numerical methodology was developed by combining GIS, the hydrologic and hydrographic characteristics of sub-basins and rainfall maps [41]. Taking into account the existing capacities and the potential of existing non-hydroelectric dams, the tool made it possible to evaluate the residual hydropower potential. The results, together with the outcomes of other studies, were presented on maps for each of the main river basins that covered all of France. Much data collection was required, which covered the following: 
- Hydrologic and hydrographic characteristics of the basins;

- Rainfall and runoff distribution;

- Characteristics of existing capacities, non-hydroelectric dams, already identified projects, and

- Various types of environmental protection, which could interfere with the development of hydroelectric projects.

Regarding existing environmental protection, a ranking process was proposed for identified hydro resources, resulting in four categories of potential from "available for development" to "non-exploitable" potential.

\subsubsection{Italy}

A methodology to evaluate the residual hydropower potential in Italy, taking into account the current uses (such as irrigation and drinking water), with a numerical technique coupled with a GIS was proposed [42]. The model applied through GIS technology coupled the hydrological and hydrographical characteristics of nearly 1,500 interconnected sub-basins and rainfall maps. Maps of maximum and residual hydropower potential were produced and were found to be quite helpful tools to support the power authorities' decision makers and other stakeholders in creating energy master plans and in implementing small hydro plants.

The macro-basin borders were obtained from the Italian digital elevation model $(90 \mathrm{~m} \times 90 \mathrm{~m}$ definition grid), through an ArcGIS tool called "Hydrology modelling". The rainfall distribution over each elementary basin was the main parameter used to determine the flow and consequently to calculate the hydropower potential. The input data were taken from the mean rainfall map, which was processed by the so-called "spline" interpolation method. The water stream discharge was obtained using the runoff coefficients. The maximum hydropower potential was determined using maps of water resource availability (that is, the discharge profiles of each river) and the related geodetic heads. Water withdrawals, including instream (ecological) flow requirements, were taken into account to determine the real residual hydropower potential for a pilot catchment. A detailed description of this interactive GIS and Web-based map, VAPIDRO ASTE, can be found at [18].

\subsubsection{Norway}

To fully understand the potential for small hydro (50 kW to $10 \mathrm{MW}$ ), the Norwegian Water and Energy Directorate (NVE) developed a new method for resource mapping using GIS technology between 2002 and 2004 [43-46]. The method involved identifying waterfalls with the potential for hydro development and then adding available hydrological data and cost figures for intakes, waterways, and power stations. ArcGIS standard hydrologic analysis was used to derive runoff. Certain limitations were set with regard to the river slope, elevation, runoff volume, maximum usable flow, installed power, and production. The plant design was fixed automatically as soon as the head and flow were known, and the power output and generation capacity was automatically calculated. This study identified 18 million MWh of potential.

A second generation version of this methodology, which resulted in the preparation of the Small Hydropower Atlas, corrected some weaknesses of the earlier method. These weaknesses included 
possible mistakes in the data used to build the DEM ( $25 \mathrm{~m} \times 25 \mathrm{~m}$ grid cells), the lack of high-quality data on distribution lines, the difficulties in assessing the correct cost for access roads, the inability of the model to include specific local conditions, and a conservative cost estimate that leads to cost figures that are too high.

Potential sites for small hydropower (NVE Atlas) are now available on the Internet, which provides developers with the location of prospective SHP plants, their power capacity and the main economic estimate, which is the total investment divided by the mean annual generation capacity, i.e., the cost of $\mathrm{kWh}$ produced [47].

\subsubsection{Scotland}

Hydrobot is a combined GIS and financial assessment tool to identify micro-hydro schemes [48]. It was first conceived as a university project and operated as a series of processes rather than a single model. The model was first used for a study commissioned by the Forum for Renewable Energy Development in Scotland on behalf of the Scottish Government to assess the nation's remaining hydro potential [49]. Hydrobot can be applied to any land area within Scotland and the top sites supplied to those developers.

Hydrobot is based on a surface flow model derived from elevation data in a $10 \mathrm{~m} \times 10 \mathrm{~m}$ grid across the whole of Scotland. Every watercourse has been modelled to give the FDC at any point. The accuracy of the predicted flows has been tested against measured flows away from established gauging stations and also examined by the Scottish Environmental Protection Agency. Hydrobot can be accessed at [50].

\subsubsection{The United States}

The Virtual Hydropower Prospector (VHP) is a GIS application designed to assist users in locating and assessing natural stream water energy resources in the United States [51]. It was developed as part of the Small Hydropower Resource Assessment and Technology Development Project conducted at the Idaho National Laboratory (INL) with the support of the U.S. Department of Energy Wind and Hydropower Technologies Program.

The intended use of VHP is to obtain a broad overview of water energy resources in an area of interest or to perform a preliminary development feasibility assessment of particular sites of interest. The location of features and the associated attribute information are for indication only. Actual on-site locations, measurements, and evaluations must be undertaken to verify information presented by VHP and assess true development feasibility. VHP was designed and developed using ESRI's commercial GIS software, ArcIMS 9.0, for the Web and mapping interface. Its main features are as follows:

- GIS tool on the Internet;

- No special software or licenses required for use;

- Displays 500,000 water energy resource sites and 130,000 feasible project sites throughout the U.S.;

- Displays context features needed to perform preliminary feasibility assessments;

- Provides tools for locating and selecting features of interest, and

- Goes beyond geographic location and provides attribute information about selected features. 
The first step in using this tool is to select one of the 20 U.S. hydrologic regions using the Region Selector available on the Internet (Virtual Hydropower Prospector) [5]. Each region selected will open a new map window for that region.

\subsubsection{Concluding Remarks}

The general features of GIS integrated software for preliminary SHP site assessment are presented in Table 3. The analysis of conventional hydro software tools for a preliminary SHP site assessment shows that, over the past 15 years, they have evolved considerably and can now account for a complex evaluation of the river basin. In particular, a large step in SHP assessment was the integration of these software tools into the GIS environment, the penetration of GIS to the Web and the advent of remote sensing techniques.

In general, for the application of GIS for assessing hydropower potential, several typical components can be identified:

- Gathering of river basin hydrological characteristics and associated attribute information as spatial GIS data and later using them for broad-based analysis;

- Development of a DEM for the river basin using a variety of primary sources as input data for GIS database development and for later use in the hydropower potential evaluation;

- Development of SHP assessment tools as specialised GIS extensions and integrating them into GIS systems;

- Performance of SHP evaluation and presentation of the results by GIS tools and their interactive use on the Internet.

In a review of GIS applications in precedent worldwide cases, not all of the steps listed above in the cases analysed were found, but some components are always available. Developers of hydropower software tools generally do not develop GIS tools themselves but prefer using standard ones or those created by others. For instance, the GIS application StreamStats is capable of computing estimates of streamflow at ungauged sites [7]. In countries with more advanced technology, they do not need to produce the DEM because it has already been developed for the whole country. Many countries have also created GIS databases of the hydrographic network and protected areas, soils and other areas. Among the cases not mentioned, it is possible to list the countries that have introduced advanced weather and water quality monitoring systems that automatically send data from monitoring points directly to GIS databases and are available on the Web (e.g., the US). In the context of SHP potential assessment using GIS tools in different countries, the required resources are quite different. 
Table 3. GIS-based Small Hydropower Atlases on the Internet.

\begin{tabular}{|c|c|c|c|c|c|c|c|c|c|c|}
\hline \multicolumn{4}{|c|}{ SHP Atlas on the Internet } & \multicolumn{7}{|c|}{ Features } \\
\hline Name & Developer & $\begin{array}{l}\text { Applicable } \\
\text { countries }\end{array}$ & Accessibility & 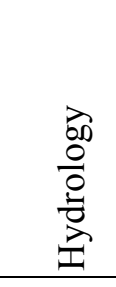 & 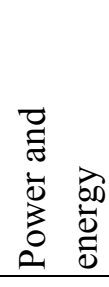 & $\begin{array}{l}0 \\
\text { 吾 } \\
0 \\
0 \\
0 \\
0 \\
0 \\
0 \\
0 \\
0\end{array}$ & 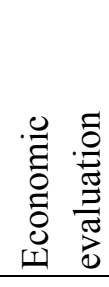 & 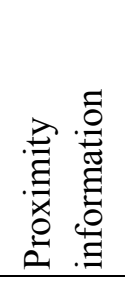 & $\begin{array}{l}0 \\
.0 \\
0 \\
0 \\
0 \\
0 \\
0 \\
0 \\
0 \\
0\end{array}$ & 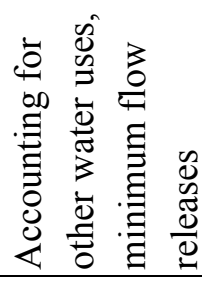 \\
\hline $\begin{array}{l}\text { NVE Atlas. Potential } \\
\text { for SHP plants [47] }\end{array}$ & $\begin{array}{l}\text { Norwegian Water } \\
\text { Resources and Energy } \\
\text { Directorate (NVE) }\end{array}$ & Norway & $\begin{array}{l}\text { Open access, } \\
\text { interactive } \\
\text { Web-based maps }\end{array}$ & MAF & + & + & + & + & - & - \\
\hline $\begin{array}{l}\text { Virtual Hydropower } \\
\text { Prospector (VHP) [5] }\end{array}$ & $\begin{array}{l}\text { Idaho National } \\
\text { Laboratory }\end{array}$ & US & $\begin{array}{l}\text { Open access, } \\
\text { interactive } \\
\text { Web-based maps }\end{array}$ & MAF & + & + & + & + & + & - \\
\hline RHAM [40] & $\begin{array}{l}\text { Kerr Wood Leidal } \\
\text { Associates Ltd (KWL) }\end{array}$ & $\begin{array}{l}\text { British } \\
\text { Columbia, } \\
\text { Canada }\end{array}$ & $\begin{array}{l}\text { Open access, } \\
\text { interactive } \\
\text { Web-based maps }\end{array}$ & $\begin{array}{l}\text { MAF/ } \\
\text { FDC }\end{array}$ & + & + & + & + & - & + \\
\hline Hydrobot [50] & $\begin{array}{l}\text { Nick Forrest Associates } \\
\text { Ltd. et al. }\end{array}$ & Scotland & Limited access & FDC & + & + & + & + & - & + \\
\hline VAPIDRO ASTE [18] & ERSE SpA, & Italy & $\begin{array}{l}\text { Open access, } \\
\text { interactive } \\
\text { Web-based maps }\end{array}$ & MAF & + & + & + & + & - & + \\
\hline
\end{tabular}

MAF: Mean annual flow; FDC: Flow duration curve. 
In most proposed hydropower assessment tools, GIS is often used for the presentation of results in the form of digital maps, which is very convenient for users. With those maps, the user can also perform a limited number of GIS operations (queries, etc.). Before moving the data into the GIS database, complex hydrological modelling can be performed, and only simulation results are later transferred to the database. An example is the development of the VAPIDRO-ASTE tool [18]. Some modules are directly integrated into the GIS environment, and some of them operate as a standalone, which performs the necessary calculations and integrates the result into the GIS database.

GIS applications for hydropower potential assessment may have a quite different approach, which obviously depends on the form of the input data resources and possibilities, to integrate developed tools into the GIS environment because there were a variety of tools developed before the appearance of the GIS software. Therefore, it is more useful to use them separately from GIS and then transfer the results into GIS.

\section{Conclusions}

- During the last 15 years, hydropower assessment tools based on computer software have improved considerably, accounting particularly for the complex integration of river catchment attributes. This improvement is due mainly to the advent of geographic information systems (GIS).

- With recent advances in GIS technology and the increased availability of high-quality topographic and hydrologic data, it is now possible to rapidly assess power potential on a widespread basis while maintaining a relatively high level of detail. In most countries, GIS data are free of charge.

- For hydropower project studies, remote sensing (e.g., LIDAR), which is becoming cost effective compared with conventional surveying, has represented a leap forward in producing digital elevation models, especially in areas that are difficult to access.

- Using DEM and regional hydrologic data, these software tools are able to calculate the amount of hydropower available on all streams in a study area, screening out sites within environmentally sensitive or excluded areas, and to estimate project costs.

- A number of countries (e.g., Canada, Italy, Norway, Scotland and the US) have re-assessed their hydropower capacities based on the spatial information of their water stream catchments, developed tools for automated hydro-site identification and published Web-based GIS tools, the so-called Atlas of small-scale hydropower resources, for open use. Their experience can be applied to other parts of the world to unlock hydropower potential.

- It is absolutely clear that a reliable assessment of real SHP site feasibility implies some "on the ground" surveying, but this traditional assessment can be greatly facilitated with computer programs if the GIS technique involving the spatial variability of catchment characteristics is integrated. 


\section{Acknowledgement}

This paper is based on the findings of the EU partially funded projects, Small Hydro Action for the Promotion of efficient solutions (SHAPES; 2007-2010; No. TREN/07/FP6EN/S07.74894/038539) and Stream Map for Small Hydropower in the EU (SHP STREAMMAP; 2009-2012; No. IEE/08/697/SI2.529232). The project coordinator was the European Small Hydropower Association (ESHA). The authors would like to thank the anonymous reviewers for their valuable comments.

\section{References}

1. Wilson, E.M. Assessment Methods for Small-Hydro Projects; Technical Report; The International Energy Agency: Paris, France, 2000.

2. International Small Hydro Atlas. Available online: http://www.small-hydro.com/index.cfm? fuseaction=planning.home (accessed on 13 June 2011).

3. Punys, P.; Dumbrauskas, A. Advances in hydrological analysis for planning and design of SHP plants. In Proceedings of the International Conference HIDROENERGIA 2010, Lausanne, Switzerland, June 2010.

4. Carroll, G.; Rieves, K.; Lee, R.; Cherry, S. Evaluation of potential hydropower sites throughout the United States. In Proceedings of the ESRI International User Conference, San Diego, CA, USA, August 2004.

5. Virtual Hydropower Prospector (VHP). Available online: http://hydropower.inel.gov/prospector/ index.shtml (accessed on 13 June 2011).

6. Jorgensen, J. On trial in Clackamas County. International Water Power \& Dam Construction Magazine, July 2009, pp. 30-33.

7. United States Geological Survey. STREAMSTATS. Available online: http://water.usgs.gov/osw/ streamstats (accessed on 13 June 2011).

8. Larentis, D.G.; Collischonn, W.; Olivera, F.; Tucci, C.E.M. Gis-based procedures for hydropower potential spotting. Energy 2010, 10, 4237-4243.

9. Gismalla, Y.A.; Bruen, M. Use of a GIS in reconnaissance studies for small-scale hydropower development in a developing country: a case study from Tanzania. In Proceedings of the Conference HydroGIS 96: Application of Geographic Information Systems in Hydrology and Water Resources Management, Vienna, Austria, April 1996.

10. Ballance, A.; Stephenson, D.; Chapman, R.A.; Muller, J.A. Geographic information systems analysis of hydro power potential in South Africa. J. Hydroinform. 2000, 2, 247-254.

11. Kusrea, B.C.; Baruah, D.C.; Bordoloi, P.K.; Patra, S.C. Assessment of hydropower potential using GIS and hydrological modeling technique in Kopili River basin in Assam (India). Appl. Energy 2010, 1, 298-309.

12. Dudhani, S.; Sinha, A.K.; Inamdar, S.S. Assessment of small hydropower potential using remote sensing data for sustainable development in India. Energy Policy 2006, 34, 3195-3205.

13. Rojanamon, P.; Chaisomphob, T.; Bureekul, T. Application of geographical information system to site selection of small run-of-river hydropower project by considering engineering/economic/ environmental criteria and social impact. Renew. Sustain. Energy Rev. 2009, 13, 2336-2348. 
14. Deheragoda, C.K.M.; Gunathilaka, J.; Jayantha, H.M.P. Potential of GIS for Promotion of Renewable Energy Power Generation in Sri Lanka with Special Reference to Mini Hydro Projects. Available online: http://mapasia.org/2009/proceeding/utility/index.html (accessed on 12 June 2011).

15. Yi, C.-S.; Lee, J.-H.; Shim, M.-P. Site location analysis for small hydropower using geo-spatial information system. Renew. Energy 2010, 35, 852-861

16. Gustard, A.; Irving, K.; Rees, G.; Young, A. Hrological models for small scale hydropower assessment. In Proceedings of the Conference HIDROENERGIA 95, Milan, Italy, September 1995.

17. Felix, J. Identifier des sites pour de petits aménagements hydroélectriques. Développement d'un outil SIG. ElectroSuisse Bull. 2010, 3, 44-47.

18. Strategies to Promote Small Scale Hydro Electricity Production in Europe (S.M.A.R.T.). Available online: http://www.smarthydro.eu/?p=The_Smart_Project (accessed on 13 June 2011).

19. Peviani, M.; Alterach, J.; Daneli, A. Uniting European hydropower. International Water Power \& Dam Construction Magazine, September 2010, pp. 28-30.

20. Monk, R.; Joyce S.; Homenuke, M. Rapid Hydropower Assessment Model: Identify Hydroelectric Sites Using Geographic Information Systems. In Proceedings of the Small Hydro Conference 2009, Vancouver, Canada, April 2009.

21. Forrest, N. Hydrobot: Remote Surveys of National Hydro Resources. In Proceedings of the International Conference HIDROENERGIA 2010, Lausanne, Switzerland, June 2010.

22. Alterach, J.; Vergata, M. A method to evaluate the effective potential hydropower production applied to a case study. In Proceedings of the International Conference HIDROENERGIA 2010, Lausanne, Switzerland, June 2010.

23. Felix, J.; Dubas, A. Use of GIS to identify potential sites for small hydroelectric plants: general concepts and exemple of application. In Proceedings of the International Conference HIDROENERGIA 2010, Lausanne, Switzerland, June 2010.

24. Jia, J.; Punys, P.; Ma, J. Hydropower. In Handbook of Climate Change Mitigation; Chen, W.-Y., Seiner, J., Suzuki, T., Lackner, M., Eds.; Springer Science: New York, NY, USA, 2012; p. 45, in press.

25. Mozgeris, G.; Punys P. Lithuanian atlas of small scale hydropower resources. In Proceedings of the Conference SMALL HYDRO-98, Athens, Greece, November 1998.

26. Natural resources Canada. User Manual for Integrated Method for Power Analysis (IMP 5.0.); POWEL: Victoria, Canada, 2004.

27. Integrated method for power analysis (IMP). Available online: http://www.small-hydro.com/ index.cfm?fuseaction=planning.imp (accessed on 13 June 2011).

28. RETScreen ${ }^{\circledR}$ International. Clean Energy Decision Support Centre. Clean Energy Project Analysis: RETSCREEN ${ }^{\circledR}$ Engineering \& Cases Textbook. Small Hydro Project Analysis Chapter; Natural Resources Canada: Ottawa, Canada, 2004.

29. RETScreen ${ }^{\circledR}$. Available online: http://www.retscreen.net/ (accessed on 13 June 2011).

30. Deroo, L.; van Hecke, N.; Isambert, F. Le logiciel Peach, un outil de valorisation des petits aménagements hydroélectriques. Houille Blanche 1999, 1, 19-26.

31. PEACH. Available online: http://www.isl.fr/refpages/fr/pages/refa5r1.htm (accessed on 13 June 2011). 
32. Francfort, J.E.; Matthews, S.D.; Rinehart, B.N. Uniform Criteria for U.S. Hydropower Resource Assessment. Hydropower Evaluation Software (HES) User's Manual; Department of Energy Idaho Operations Office: Idaho Falls, ID, USA, 2002.

33. Hydropower Evaluation Software (HES). Available online: http://hydropower.inel.gov/ resourceassessment/software/ (accessed on 13 June 2011).

34. OEL HYDROSYS. HydroHelp Series of Hydro Design and Cost Programs - a Description with Examples of Program Screens, Canada, 2008. Available online: http://hydrohelp.ca/eng/home.htm (accessed on 13 June 2011).

35. Burrough, P.A.; Mcdonnell, R.A. Principles of Geographical Information Systems, 2nd ed.; Oxford University Press: Oxford, UK, 1998; p. 327.

36. Verner, J.S. User experience with the Hydrohelp programs. In Proceedings of the Small Hydro Conference 2009, Vancouver, BC, Canada, April 2009.

37. Maidment, D.R. ArcHydro: GIS for Water Resources; ESRI Press: Redlands, CA, USA, 2002; p. 220.

38. Maidment, D.R.; Djokic, D. Hydrologic and Hydraulic Modeling Support with Geographic Information Systems; ESRI Press: Redlands, CA, USA, 2000; p. 232.

39. Kerr Wood Leidal Associates Ltd. (KWL). Run-of-River Hydroelectric Resource Assessment for British Columbia; Final Report; BC Hydro, BC Transmission Corporation: Vancouver, BC, Canada, 2007.

40. Kerr Wood Leidal Associates Limited. Rapid Hydro Assessment Model (RHAM). Available online: http://www.rapidhydro.ca/ (accessed on 13 June 2011).

41. Crépon, O. Re-assessing French hydropower potential. Int. J. Hydropower Dams 2009, 5, 47-49.

42. Alterach, J.; Lterach, J.; Pevani, M.; Davitti, A.; Vergata, M.; Ciaccia, G.; Fontini, F. Evaluation of the remaining hydro potential in Italy. Int. J. Hydropower Dams 2009, 5, 56-59.

43. Jensen, T. Estimation of the Potential for Small Power Plants in Norway; Report No. 19; Norwegian Water Resources and Energy Directorate: Oslo, Norway, 2004.

44. Jensen, T. Building Small Hydro in Norway. HRW 2008, 4, $20-27$.

45. Voksø, A. Using GIS to calculate potential for small hydro power plants in Norway. In Proceedings of the XXV Nordic Hydrological Conference, Nordic Association for Hydrology, Reykjavik, Iceland, August 2008.

46. Lytskjold, B. Geographical Information System (GIS) at NVE. NVE, Geoinformation Section: Oslo, Norway, November, 2009. Available online: http://www.nve.no/PageFiles/8427/GIS\% 20in\% 20Hydrology\%2019Nov09.pdf (accessed on 13 June 2011).

47. NVE Atlas: Potential Sites for Small Hydropower. Available online: http://arcus.nve.no/website/ potensial_smaakrv/viewer.htm (accessed on 13 June 2011).

48. Forrest, N. Getting to the bottom of it-identifying hydro sites. International Water Power \& Dam Construction Magazine, January 2009, pp. 42-44.

49. Scottish Hydropower Resource Study; Final Report to the Scottish Government through the Hydro Sub Group (FHSG) Nick Forrest Associates Ltd.; Scottish Institute of Sustainable Technology (SISTech) and Black \& Veatch Ltd.: Edinburgh, UK, 2008.

50. Hydrobot. Available online: http://www.nickforrestassoc.co.uk/tilemap.php (accessed on 13 June 2011). 
51. Hall, D.G.; White, S.E.; Brizzee, J.A.; Lee, R.D. User's Guide. Virtual Hydropower Prospector; Version 1.1; Idaho National Laboratory: Idaho Falls, ID, USA, 2005.

(C) 2011 by the authors; licensee MDPI, Basel, Switzerland. This article is an open access article distributed under the terms and conditions of the Creative Commons Attribution license (http://creativecommons.org/licenses/by/3.0/). 